\title{
Drought Effects on Physiology and Biochemistry of Pedunculate Oak (Quercus robur L.) and Hornbeam (Carpinus betulus L.) Saplings Grown in Urban Area of Novi Sad, Serbia
}

\author{
Srđan Stojnić ${ }^{1 *}$, Saša Pekeč ${ }^{1}$, Marko Kebert ${ }^{1}$, Andrej Pilipović ${ }^{1}$, Dejan Stojanović ${ }^{1}$, Marko Stojanović ${ }^{1,2}$, \\ Saša Orlović ${ }^{1}$
}

(1) University of Novi Sad, Institute of Lowland Forestry and Environment, Antona Čehova 13, RS-21000 Novi Sad, Serbia; (2) Mendel University, Faculty of Forestry and Wood Technology, Zemědělská 3, CZ-613 00 Brno, Czech Republic

* Correspondence: e-mail: srdjan.stojnic@uns.ac.rs
Citation: STOJNIĆ S, PEKEČ S, KEBERT M, PILIPOVIĆ A, STOJANOVIĆ D, STOJANOVIĆ M, ORLOVIĆ S 2016 Drought Effects on Physiology and Biochemistry of Pedunculate Oak (Quercus robur L.) and Hornbeam (Carpinus betulus L.) Saplings Grown in Urban Area of Novi Sad, Serbia. South-east Eur for 7 (1): 57-63. DOI: http:// dx.doi.org/10.15177/seefor.16-03

Received: 30 Oct 2015; Revised: 27 Jan 2016; Accepted: 29 Jan 2016; Published online: 15 Feb 2016

\begin{abstract}
Background and Purpose: Water stress is one of the major problems for urban trees. It affects a wide range of plant responses, from changes at the cellular level to the reduction in growth rates. Irrigation of trees in urban areas may provide numerous benefits important for increasing tree vitality to withstand other stresses that might occur. The aim of this study was to compare drought effects on some physiological and biochemical performances of Pedunculate oak (Quercus robur L.) and Hornbeam (Carpinus betulus L.) saplings grown in the urban area.

Materials and Methods: The study was conducted during August 2012 at the Boulevard of Europe (Novi Sad, Republic of Serbia). Measurements were carried out on saplings grown in the part of the boulevard with drip irrigation system installed (Site 1) and on the saplings cultivated in the part without any irrigation system (Site 2).

Results: Soil moisture content was significantly higher at Site 1 with approximately $57.2 \%$, compared to $18.7 \%$ at Site 2 . The results showed that irrigated saplings were characterized by significantly higher stomatal conductance in $Q$. robur and $C$. betulus. Similarly, the content of free proline, FRAP units and the amount of malonyldialdehyde showed increased values in trees subjected to soil water deficit. In contrast, net photosynthesis, chlorophyll and carotenoid contents did not differ notably in irrigated and non-irrigated $Q$. robur and $C$. betulus trees.

Conclusions: Water stress significantly affected stomatal conductance and some biochemical properties of $Q$. robur and $C$. betulus saplings cultivated at the non-irrigated site. The results showed that the implementation of drip irrigation system in urban landscape is an important tool in the prevention of drought stress effects on the physiological processes of plants.
\end{abstract}

Keywords: drought, irrigation, physiology, biochemistry, pedunculate oak, hornbeam, urban area

\section{INTRODUCTION}

Urban trees are integral components of urban ecosystems and provide a wide range of ecosystem services important for urban citizens [1, 2]. By transpiring water, removing air pollutants, reducing noise, altering wind speeds, enhancing urban biodiversity, shading surfaces, changing the microclimate, and modifying the storage and exchanges of heat among urban surfaces [3, 4], urban trees contribute to improving environmental quality, quality of life, and sustainable urban development $[5,6]$.

However, there are a number of biotic and abiotic stressors that urban trees have to cope with, such as: heat island effect, limited soil moisture, the presence of detrimental contaminants in the soil (e.g. salt, oils, heavy metals and organic pollutants), air pollution, tree pests and 
diseases, constructions, mechanical damages to root, trunk and branches, etc [7]. Lack of moisture in the soil is one of the most common problems that affect trees in urban environments [8]. Water stress affects a wide range of plant responses, from changes at the cellular level to the reduction in growth rates [9]. For example, Popović et al. [10] found that photosynthetic efficiency of pedunculate oak seedlings was significantly affected by short-term water stress. Bréda et al. [11] reported that sap flux densities and stomatal conductance were reduced by almost $70 \%$ at maximal drought intensity in adult Quercus robur and Quercus petraea trees. Ježík et al. [12] found that reduced water availability caused much lower tree water status and stem circumference increase in non-irrigated Norway spruce trees. Similarly, a study by Pšidová et al. [13] showed significant reduction of net photosynthesis and stomatal conductance in beech seedlings subjected to water deficit.

In urban conditions soil moisture is often limited due to soil compaction and reduced soil volume [14]. In such circumstances, water supply decreases in the root system because compacted soils, together with street structures, prevent infiltration of water into the root zone. At the same time, access to the ground water and subsurface drainage is often eliminated due to restricted rooting volume [15]. As a consequence of aforementioned disturbances, the life-span of trees growing in urban environments can be significantly shortened in comparison with trees growing in natural habitats [16].

In the present study we examined drought effects on physiological and biochemical performances of Pedunculate oak (Quercus robur L.) and Hornbeam (Carpinus betulus L.) saplings grown under two watering regimes - irrigated and non-irrigated. The objective of the study was to examine to which extent, for period of one month, the soil water deficit at the site without irrigation system will affect different physiological and biochemical proceses in trees and to indentify those traits that react most sensitively, and thus might be used as early signs of water stress. Since the mortality rate of saplings is the highest in the first year after planting, the present study was conducted at newly established boulevard and involved recently planted saplings of the same age.

\section{MATERIALS AND METHODS}

\section{Experimental Location and Plant Material}

The study was conducted during August 2012, at the Boulevard of Europe (Novi Sad, Republic of Serbia). The Boulevard of Europe was built in 2010. After finishing the constructions of the road, the bicycle path and the footpath, green area was established along the entire boulevard. For that purpose, six-year-old saplings of Pedunculate oak (Quercus robur L.) and Hornbeam (Carpinus betulus L.) were planted. The space between the saplings was $10 \times$ $10 \mathrm{~m}$. In order to prevent the negative effects of drought stress on the saplings, drip irrigation system was installed in one part of the boulevard. In order to examine how irrigation affects plants' physiological performances, the measurements were carried out on saplings grown in the part of the boulevard with irrigation system installed (between Futoška Ulica and Bulevar Vojvode Stepe) (Site 1) and on the saplings cultivated in the part without any irrigation system installed (between Bulevar Vojvode Stepe and Rumenačka Ulica) (Site 2).

The climate of Novi Sad is temperate continental with a mean annual temperature of $11.4^{\circ} \mathrm{C}$ and annual precipitation sum of $647 \mathrm{~mm}$. Mean air temperature during the vegetation period (April-September) is $18.3^{\circ} \mathrm{C}$, while the sum of precipitations for the same period amounts to 379 $\mathrm{mm}$. The climate records were acquired from the weather station Rimski Sancevi (N 4520', E 1951'; 84 m a.s.l.), at $10 \mathrm{~km}$ distance from the city (http://www.hidmet.gov.rs). Temperature and precipitation have been averaged for the time period between 1981 and 2010.

\section{Soil Analysis}

Soil samples were taken from irrigated and non irrigated sites (two samples per each site). The physical characteristics of soil were determined according standard laboratory analyses. Particle size distribution (\%) was determined by the international B-pipette method with preparation in sodium pyrophosphate [17], while the determination of soil textural classes was carried out based on particle size distribution using Atteberg classification [18] and $\mathrm{pH}$ in $\mathrm{H}_{2} \mathrm{O}$ electrometric method with combined electrodes on $\mathrm{pH}$ meter. Soil moisture content was determined according to Bošnjak et al. [17], whereas humus percentage (\%) in soil was determined by Tjurin method in Simakov's modification [19]. The Kjeldahl method was applied for the determination of nitrogen percentage (\%) in soil [20].

\section{Gas Exchange Measurements}

Net photosynthesis (A) and stomatal conductance (gs) were measured using the ADC BioScientific Ltd. LCpro+ Portable Photosynthesis System. Leaves were enclosed in the broad leaf chamber until the values of $A$ and gs had stabilized (usually about 60 seconds) [21]. Measurement was conducted in 5 replications on 5 plants per single species. Fully expanded leaves of the same developmental age, with the same orientation, placed in the upper part of the crown were used as samples. Measurements were done in sunny and clear weather, in the period between 09:00 and 11:00 a.m. Measurements were done under constant light conditions (PAR $1000 \mu \mathrm{mol} \cdot \mathrm{m}^{-2} \cdot \mathrm{s}^{-1}$ ) and $\mathrm{CO}_{2}$ concentration $\left(350 \mu \mathrm{mol} \cdot \mathrm{mol}^{-1}\right)$. The air supply unit provided a flow of ambient air to the leaf chamber at a constant rate of 100 $\mu \mathrm{mol} \cdot \mathrm{s}^{-1}$. Temperature and humidity inside of chamber were at the ambient level [22].

\section{Determination of Photosynthetic Pigment Concen- tration}

The contents of chlorophyll a ( Chl a), chlorophyll b (Chl b) and carotenoids (Car) were determined according to Wettstein method [23] in acetone solution. Absorbances at wavelengths $662 \mathrm{~nm}$ (chlorophyll a), 644 (chlorophyll b) and $440 \mathrm{~nm}$ (carotenoids) were measured by spectrophotometer and expressed in $\mathrm{mg} \cdot \mathrm{g}^{-1}$ of dry weight (DW). 


\section{Determination of Oxidative Stress}

Extracts were homogenized and macerated with 10

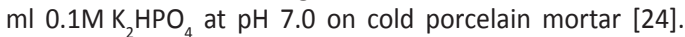
Homogenate was centrifuged for 10 minutes at $4000 \mathrm{~g}$. Finally, the resulting supernatant was mixed with glycerol in 1:1 ratio and the mixture was used for the determination of: (a) free proline (FP) accumulation, (b) total antioxidant activity and (c) lipid peroxidation intensity. Proline accumulation was determined by the method described by Bates et al. [25]. Proline was determined after the extraction with 5-sulphosalicyclic acid and the reaction with ninhydrin. A standard curve of proline was used for calibration. Total antioxidant capacity was estimated according to the FRAP (Ferric Reducing Antioxidant Power) assay [26]. Total reducing power was expressed in FRAP units. FRAP unit is equal to $100 \mu \mathrm{mol} \cdot \mathrm{dm}^{-3} \mathrm{Fe}^{2+}$. FRAP value is calculated using the formula: $F R A P$ value $=\Delta \mathrm{A}_{\text {sample }} / \Delta \mathrm{A}_{\text {standard }}$.

Lipid peroxidation was determined by the thiobarbituric acid (TBA) method. Values were given based on the quantification of an end-product malonyldialdehyde (MDA) and expressed as nmol MDA.g-1 fresh weight (FW) [27].

\section{Statistical Analysis}

The data were analysed with statistical software package Statistica 10 [28]. Differences between two treatments were analyzed using One-way ANOVA procedure. Significance was determined at $p<0.05$ throughout the entire analysis.

\section{RESULTS}

Site 1 was characterized by textural class of sandy loam, contrary to Site 2 where predominant texture classes were loam (Site 2, S3) and sandy-loam (Site 2, S4). In irrigated area (Site 1), instantaneous soil moisture content ranged from $38.1 \%$ to $61.0 \%$ in the surface layers $(0-10 \mathrm{~cm})$, while in the deeper layers $(10-40 \mathrm{~cm})$ soil moisture content increased due to the reduced evaporation, and ranged from $36.0 \%$ to $93.8 \%$. In contrast, lower soil moisture content was observed in non-irrigated area (Site 2). Soil mosture content varied between $12.9 \%$ to $13.8 \%$ in the surface layers, and between $21.6 \%$ and $26.4 \%$ in the lower layers (Table 1 ).
The results of irrigation effects on physiological performances of pedunculate oak and hornbeam saplings are shown in Figure 1. On the non-irrigated site both species had significantly decreased gs $\left(p_{\text {arobur }}<0.003\right.$; $p_{\text {c.betulus }}<0.002$ ), whereas differences in net photosynthesis were not statistically significant, even though $A$ decreased in non-irrigated saplings of both species. Notable differences between treatments were also observed for free proline content $\left(p_{\text {o.robur }}<0.003 ; p_{\text {c.betulus }}<0.001\right)$, FRAP $\left(p_{\text {a.robur }}<0.001\right.$; $\left.\mathrm{p}_{\text {c.betulus }}<0.001\right)$ and lipid peroxidation $\left(\mathrm{p}_{\text {a.robur }}<0.005 ; \mathrm{p}_{\text {c.betulu }}\right.$ $<0.022$ ) (Figure 1).

The chlorophyll and carotenoid content was not significantly different between saplings grown under two watering regimes. In oak saplings, $\mathrm{Chl}$ a, $\mathrm{Chl} \mathrm{a+b}$ and $\mathrm{Car}$ were higher in the leaves of irrigated plants, while $\mathrm{Chl} b$ content was higher in plants subjected to water deficit. On the contrary, higher content of $\mathrm{Chl} \mathrm{a,} \mathrm{Chl} \mathrm{b,} \mathrm{Chl} \mathrm{a+b} \mathrm{and} \mathrm{Car}$ occurred in stressed hornbeam plants.

\section{DISCUSSION AND CONCLUSIONS}

The results of our study showed that $A$ and gs were reduced in non-irrigated saplings of both tree species. It corresponds to the results of Gallé and Feller [29] who reported that $A$ and gs in beech seedlings decreased in parallel with increased water deficit. Similar findings were reported by Krstić et al. [21] for Acer pseudoplatanus and Platanus acerifolia saplings cultivated on undeveloped alluvial soil. However, even though net photosynthesis declined at Site 2, the analysis of variance did not reveal statistically significant differences between saplings grown at Site 1 and Site 2. In contrast, stomatal conductance was more sensitive to soil water deficit, displaying a proportionally greater reduction under stress compared to the rate of photosynthesis, as it was already detected by Valadares et al. [30] for eucalyptus hybrids. Although a number of studies demonstrated synchronized decline of stomatal conductance and net photosynthesis $[13,29,31,32]$, recent studies showed that net photosynthesis may not be necessarily affected by the reduction of stomatal conductance. Indeed, Hasanuzzaman et al. [33] reported that stomatal conductance showed

TABLE 1. Physical and chemical soil properties at the sites with irrigation (Site 1) and without irrigation (Site 2), at the Boulevard of Europe (Novi Sad, Republic of Serbia).

\begin{tabular}{|c|c|c|c|c|c|c|c|c|}
\hline Site & Soil samples & $\begin{array}{c}\text { Depth } \\
(\mathrm{cm})\end{array}$ & $\begin{array}{l}\text { Soil moisture } \\
\text { (\% vol.) }\end{array}$ & $\begin{array}{c}\text { pH } \\
\left(\text { in } \mathrm{H}_{2} \mathrm{O}\right)\end{array}$ & $\begin{array}{c}\text { Humus } \\
(\%)\end{array}$ & $\begin{array}{c}\mathbf{N} \\
(\%)\end{array}$ & $\mathrm{C} / \mathrm{N}$ & Textural class \\
\hline \multirow{4}{*}{ Site 1} & \multirow{2}{*}{ S1 } & $0-10$ & 60.97 & 8.18 & 2.73 & 0.137 & 11.56 & Sandy loam \\
\hline & & $10-40$ & 93.83 & 8.13 & 2.14 & 0.113 & 10.98 & Sandy loam \\
\hline & \multirow{2}{*}{ S2 } & $0-10$ & 38.11 & 8.18 & 1.61 & 0.089 & 10.51 & Sandy loam \\
\hline & & $10-40$ & 36.00 & 8.15 & 1.62 & 0.089 & 10.52 & Sandy loam \\
\hline \multirow{4}{*}{ Site 2} & \multirow{2}{*}{ S3 } & $0-10$ & 13.76 & 8.63 & 1.29 & 0.073 & 10.32 & Loam \\
\hline & & $10-40$ & 21.61 & 8.43 & 1.46 & 0.081 & 10.41 & Loam \\
\hline & \multirow{2}{*}{ S4 } & $0-10$ & 12.87 & 8.18 & 1.25 & 0.070 & 10.31 & Sandy loam \\
\hline & & $10-40$ & 26.39 & 8.23 & 1.19 & 0.067 & 10.30 & Sandy-clay loam \\
\hline
\end{tabular}



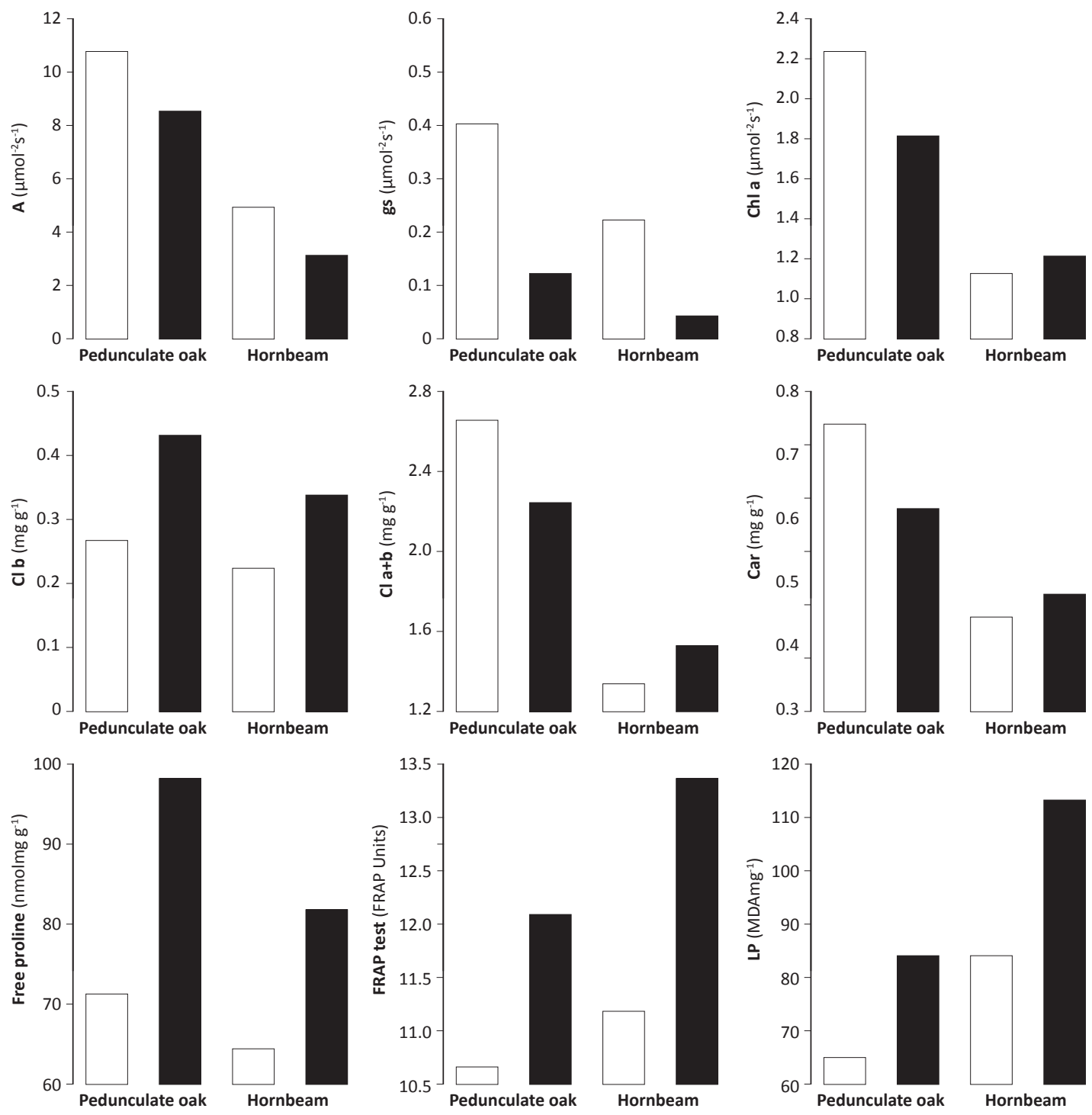

FIGURE 1. Physiological and biochemical performances of irrigated ( $\square$ ) and non-irrigated ( $\square$ ) Pedunculate oak and Hornbeam saplings grown in urban area of Novi Sad, during August 2012.

an earlier decline under mild to moderate stress than net photosynthesis, which abruptly dropped only at severe stress. Likewise, study on drought stress response in Jatropha curcas showed that despite the tight stomatal regulation under mild and moderate water stress, stomatal limitations to photosynthesis only occurred under severe stress [34]. Since the photosynthesis was not affected in $Q$. robur and $C$. betulus saplings even under sustained reductions of stomatal conductance, we might assume that the photosynthetic apparatus of both species is likely to be resistant to mild to moderate water stress. It corresponds to the findings of Michelozzi et al. [35] for Aleppo pine provenances.
Several studies demonstrated that under drought stress leaf chlorophyll contents often decline as a consequence of chlorophyll degradation $[36,37]$. In this study we found no reduction in photosynthetic pigment contents. In fact, some increase was observed in hornbeam saplings, but it was not significant. This has also been reported for J. curcas [34] and F. sylvatica [38].

Significant increase of total antioxidant activity estimated by FRAP test was recorded under drought treatment in both species inspected. These results indicate that drought induces biosynthesis of chemical compounds with high antioxidant properties in order to cope with 
oxidative stress which is a direct consequence of drought due to fact that reactive oxygen species (ROS) are generated abundantly under drought conditions. Within these groups of metabolites the most dominant are the products of secondary metabolism; in first line the phenolic compounds, both glicosides and aglicons, tannins, polyamines and conjugated polyamines all with a high capacity to scavenge reactive oxygen species. Štajner et al. [39] presented similar results where they tracked radical scavenger capacities as well as ferric reducing ability of extracts under different stress conditions in six melliferous woody plant species where they stated similar results of significantly increased FRAP value under the drought stress dominantly observed in Fraxinus and Tillia species.

Another plant mechanism to suppress consequences of drought conditions is by accumulation of osmoprotective compounds which have an important role in osmoregulation and in the maintenance of the water regime. Proline, like immino acid, due to its polarity is very often referred to as one of the main osmoprotectants. In this study, the concentration of free proline was significantly increased under the non-irrigated conditions both in oaks (increase of $28 \%$ ) as well as in hornbeams (increase of $30.7 \%$ ) compared to watered controls. Our findings are consistent with the results reported by $\mathrm{Hu}$ et al. [40] who evidenced that foliar proline levels were enhanced in the drought plus air warming treatment across three oak species (Quercus robur, Quercus petraea and Quercus pubescens). Similarly, the simultaneous measurement of proline and related compounds on the leaves of drought stressed Quercus robur plants showed that fifty-six days of water deficit exposure resulted in increased foliar free proline levels of drought stressed oak compared to well-watered control [41]. Finally, Topić [42] found that free proline content in the leaves Quercus robur seedlings subjected to drought stress was almost twice higher in comparison to control treatment. Our findings are in accordance with the results that were gained from other tree species as well. For example, studying the influence of three different water regimes $(100,50$, and $25 \%$ of the field capacity) on two contrasting populations of Populus przewalskii, Lei at al. [43] found that drought not only significantly affected decreased chlorophyll pigment contents but also caused accumulation of the free proline and total amino acids as well as abscisic acid and hydrogen peroxide. In their research, Szabados and Savoure [44] highlighted the important role of proline as an antioxidant that is acting as a single oxygen quencher and a $\mathrm{H}_{2} \mathrm{O}_{2}$ scavenger, but that it can also reduce lipid peroxidation intensity.

Furthermore, the intensity of lipid peroxidation process measured by the quantification of its end-product malonyldialdehyde was also found markedly elevated under drought stress, which implies that drought stress caused by a lack of irrigation stimulates a very detrimental process of peroxidation of membranes' lipids. Schwanz and Polle [45] in their comparative study also found a significantly elevated intensity of lipid peroxidation under the drought stress in $Q$. robur which they characterized as a more drought tolerant species compared to Pinus pinaster. This is due to the features of $Q$. robur such as higher activities of superoxide dismutase, ascorbate peroxidase, catalase, dehydroascorbate reductase and glutathione reductase. Also, same authors referred to the significant loss of chlorophylls and carotenoids as well as soluble proteins under the drought stress.

All the gained results confirmed that both oaks and hornbeam species share same physiological and biochemical mechanism to cope with water limitation, which is reflected in the decline of stomatal conductance, the increase of total antioxidant activity through the induction of biosynthesis of compounds with high antioxidant properties as well as the elevated accumulation of proline as an osmoregulatory amino acid. This all as a consequence leads to mitigation of lipid peroxidation and general oxidative stress which were induced significantly under the inspected drought stress. Considering all the facts, our main conclusion is that irrigation in urban areas could drastically improve the general fitness of the plants since in this study it was confirmed that irrigation beneficially affects plants on physiological and biochemical level, which enables them more feasible growth and development, which contributes to healthier environment, affects the microclimate, provides more shade and filters the air.

\section{REFERENCES}

1. DWYER JF, SCHROEDER HW, GOBSTER PH 1991 The significance of urban trees and forests: toward a deeper understanding of values. J Arboric 17 (10): 276-284

2. BOLUND P, HUNHAMMAR S 1999 Ecosystem services in urban areas. Ecol Econ 29 (2): 293-301. DOI: http://dx.doi. org/10.1016/S0921-8009(99)00013-0

3. NOWAK DJ, DWYER JF 2007 Understanding the benefits and costs of urban forest ecosystems. In: Kuser JE (ed) Urban and Community Forestry in the Northeast, 2nd edition. Springer Netherlands, Netherlands, pp 25-46. DOI: http://dx.doi. org/10.1007/978-1-4020-4289-8 2

4. ŽIVOJINOVIĆ I, WOLFSLEHNER B, TOMIĆEVIĆ-DUBLJEVIĆ J 2015 Social and Policy Aspects of Climate Change Adaptation in Urban Forests of Belgrade. South-east Eur for 6 (2): 219235. DOI: http://dx.doi.org/10.15177/seefor.15-20
5. JIM CY, CHEN WY 2009 Ecosystem services and valuation of urban forests in China. Cities 26 (4): 187-194. DOI: http:// dx.doi.org/10.1016/i.cities.2009.03.003

6. SAVČIĆ B, STEVANOV M, STAMENOVSKI N 2012 Alleys of Novi Sad: Perceptions and opinions of citizens about existing urban green areas (in Serbian with English summary). Topola 191-192: 101-116

7. SAEB $\varnothing$ A, BORZAN Z, DUCATILLION C, HATZISTATHIS A, LAGERSTRÖM T, SUPUKA J, GARCÍA-VALDECANTOS JL, REGO F, VAN SLYCKEN J 2005 The Selection of Plant Materials for Street Trees, Park Trees and Urban Woodland. In: Konijnendijk C, Nilsson K, Randrup T, Schipperijn J (eds) Urban Forests and Trees. Springer Berlin Heidelberg, Berlin, Germany, pp 257280. DOI: http://dx.doi.org/10.1007/3-540-27684-X 11 
8. SAEB $\varnothing$ A, BENEDIKZ T, RANDRUP TB 2003 Selection of trees for urban forestry in the Nordic countries. Urban For Urban Gree 2 (2): 101-114. http://dx.doi.org/10.1078/1618-8667$\underline{00027}$

9. HSIAO TC 1973 Plant responses to water stress. Ann Rev Plant Physio 24: 519-570. DOI: http://dx.doi.org/10.1146/annurev. pp.24.060173.002511

10. POPOVIĆ Z, MILANOVIĆ S, MILETIĆ Z, SMILJANIĆ M 2010 Photosynthetic efficiency of Pedunculate oak seedlings under simulated water stress. Bulletin of the Faculty of Forestry 101: 139-150. DOI: http://dx.doi.org/10.2298/GSF1001139P

11. BRÉDA N, COCHARD H, DREYER E, GRANIER A 1993 Field comparison of transpiration, stomatal conductance and vulnerability to cavitation of Quercus petraea and Quercus robur under water stress. Ann For Sci 50 (6): 571-582. DOI: http://dx.doi.org/10.1051/forest:19930606

12. JEŽíK M, BLAŽENEC M, LETTS MG, DITMAROVÁ L, SITKOVÁ Z, STŘELCOVÁ K 2015 Assessing seasonal drought stress response in Norway spruce (Picea abies (L.) Karst.) by monitoring stem circumference and sap flow. Ecohydrology 8 (3): 378-386. DOI: $h$ ttp://dx.doi.org/10.1002/eco.1536

13. PŠIDOVÁ E, DITMAROVÁ L', JAMNICKÁ G, KURJAK D, MAJEROVÁ J, CZAJKOWSKI T, BOLTE A 2015 Photosynthetic response of beech seedlings of different origin to water deficit. Photosynthetica 53 (2): 187-194. DOI: http://dx.doi. org/10.1007/s11099-015-0101-x

14. DEGAETANO AT 2000 Specification of soil volume and irrigation frequency for urban tree containers using climate data. J Arboric 26 (3): 142-151

15. WHITLOW TH, BASSUK NL, REICHERT DL 1992 A 3-year study of water relations of urban street trees. J Appl Ecol 29 (2): 436-450. DOI: http://dx.doi.org/10.2307/2404512

16. WHITLOW TH, BASSUK NL 1988 Ecophysiology of urban trees and their management - the North American experience. HortScience 23 (3): 542-546

17. BOŠNJAK $Đ$, DRAGOVIĆ $S$, HADŽIĆ $V$, BABOVIĆ $V$, KOSTIĆ $N$, BURLICA Č, ĐOROVIĆ M, PEJKOVIĆ M, et al. 1997 Metode istraživanja i određivanja fizičkih svojstava zemljišta (in Serbian). JDPZ, Beograd, Srbija, $278 \mathrm{p}$

18. HADŽIĆ V, BELIĆ M, NEŠIĆ L 2004 Praktikum iz pedologije (in Serbian). Poljoprivredni fakultet, Departman za ratarstvo i povrtarstvo, Novi Sad, Srbija, $80 \mathrm{p}$

19. ŠKORIĆ A, SERTIĆ V 1966 Analiza organske materije (humusa) u zemljištu (in Serbian). Priručnik za ispitivanje zemljišta knjiga I - Hemijske metode ispitivanja zemljišta, JDPZ, Beograd, Srbija, 41-46 p

20. BREMNER JM 1960 Determination of nitrogen in soil by the Kjeldahl method. J Agric Sci 55 (1): 11-33. DOI: http://dx.doi. org/10.1017/S0021859600021572

21. KRSTIĆ J, ORLOVIĆ S, GALIĆ Z, PILIPOVIĆ A, STOJNIĆ S 2014 Seasonal changes in leaf gas exchange parameters in Platanus acerifolia Willd. and Acer pseudoplatanus L. seedlings on undeveloped alluvial soil (fluvisol). Šumarstvo 1-2: 163-178

22. TOPIĆ M, BORIŠEV M, ŽUPUNSKI M, TOMIČIĆ M, NIKOLIĆ N, PAJEVIĆ S, KRSTIĆ B, PILIPOVIĆ A 2012 Recovery responses of photosynthesis, transpiration, and wue in black poplar clones following water deficits. Topola 189-190: 29-38

23. WETTSTEIN D 1957 Chloropyll-letale und submikroskopische formwechsel der plastiden. Exp Cell Res 12 (3): 427-506. DOI: http://dx.doi.org/10.1016/0014-4827(57)90165-9

24. TRUDIĆ B, KEBERT M, POPOVIĆ MB, ŠTAJNER D, ORLOVIĆ $S$, GALOVIĆ V 2012 The level of oxidative stress in poplars due to heavy metal pollution in soil. Balt For 18 (2): 214-227

25. BATES CJ, WALDREN RP, TEARE ID 1973 Rapid determination of free proline for water-stress studies. Plant Soil 39 (1): 205207. DOI: http://dx.doi.org/10.1007/BF00018060

26. BENZIE IFF, STRAIN JJ 1999 Ferric reducing antioxidant power assay: Direct measure of total antioxidant activity of biological fluids and modified version for simultaneous measurement of total antioxidant power and ascorbic acid concentration. Method Enzymo/ 299: 15-27. DOI: http://dx.doi.org/10.1016/ S0076-6879(99)99005-5
27. PLACER ZA, CUSTMAN N, HOHNSON BC 1968 Estimation of product of lipid peroxidation (malonyldialdehyde) in biochemical system. Anal Biochem 16 (2): 359-364. DOI: http://dx.doi.org/10.1016/0003-2697(66)90167-9

28. STATSOFT, INC. 2011 STATISTICA (data analysis software system), version 10. www.statsoft.com

29. GALLÉ A, FELLER U 2007 Changes of photosynthetic traits in beech saplings (Fagus sylvatica) under severe drought stress and during recovery. Physiol Plantarum 131 (3): 412-421. DOI: http://dx.doi.org/10.1111/j.1399-3054.2007.00972.x

30. VALADARES J, PAULA NF, PAULA RC 2015 Physiological changes in eucalyptus hybrids under different irrigation regimes. Rev Ciênc Agron 45 (4): 805-814. DOI: http://dx.doi. org/10.1590/S1806-66902014000400019

31. RAFTOYANNIS Y, RADOGLOU K, HALIVOPOULOS G 2006 Ecophysiology and survival of Acer pseudoplatanus L., Castanea sativa Miller. and Quercus frainetto Ten. seedlings on a reforestation site in northern Greece. New Forest 31 (2): 151-163. DOI: $h \mathrm{ttp}: / / d x$.doi.org/10.1007/s11056-004-7365-5

32. CHENG X, HE Z, YU M, YIN Z 2014 Gas exchange characteristics of the hybrid Azadirachta indica $\times$ Melia azedarach. iForest 8: 431-437. DOI: http://dx.doi.org/10.3832/ifor1127-007

33. HASANUZZAMAN M, NAHAR K, GILL SS, FUJITA M 2013 Drought stress responses in plants, oxidative stress, and antioxidant defense. In: Tuteja N, Gill SS (eds) Climate change and plant abiotic stress tolerance. Wiley-VCH Verlag $\mathrm{GmbH}$ \& Co. KGaA, Weinheim, Germany, pp 209-250. DOI: http:// dx.doi.org/10.1002/9783527675265.ch09

34. SAPETA H, COSTA JM, LOURENCOT, MAROCO J, VAN DER LINDE P, OLIVEIRA NM 2013 Drought stress response in Jatropha curcas: growth and physiology. Environ Exp Bot 85: 76-84. DOI: http://dx.doi.org/10.1016/j.envexpbot.2012.08.012

35. MICHELOZZI M, LORETO F, COLOM R, ROSSI F, CALAMASSI R 2011 Drought responses in Aleppo pine seedlings from two wild provenances with different climatic features. Photosynthetica 49 (4): 564-572. DOI: http://dx.doi. org/10.1007/s11099-011-0068-1

36. KIANI SP, MAURY P, SARRAFI A, GRIEU P 2008 QTL analysis of chlorophyll fluorescence parameters in sunflower (Helianthus annuus L.) under well-watered and waterstressed conditions. Plant Sci 175 (4): 565-573. DOI: http:// dx.doi.org/10.1016/i.plantsci.2008.06.002

37. ANJUM SA, XIE X, WANG L, SALEEM MF, MAN C, LEI W 2011 Morphological, physiological and biochemical responses of plants to drought stress. Afr J Agric Res 6 (9): 2026-2032

38. BORIŠEV M, HORAK R, PAJEVIĆ S, ORLOVIĆ S, NIKOLIĆ N, ŽUPUNSKI M, PILIPOVIĆ A 2015 Daily dynamics of photosynthetic parameters in beech population under periodical drought conditions. Open Life Sci 10 (1): 165-174. DOI: http://dx.doi.org/10.1515/biol-2015-0022

39. ŠTAJNER D, ORLOVIĆ S, POPOVIĆ B, KEBERT M, GALIĆ Z 2011 Screening of drought oxidative stress tolerance in Serbian melliferous plant species. Afr J Biotechnol 10 (9): 1609-1614

40. HU B, SIMON J, RENNENBERG H 2013 Drought and air warming affect the species-specific levels of stress-related foliar metabolites of three oak species on acidic and calcareous soil. Tree Physiol 33 (5): 489-504. DOI: http:// dx.doi.org/10.1093/treephys/tpt025

41. OUFIR $M$, SCHULZ N, SHA VALLIKHAN PS, WILHELM E, BURG K, HAUSMAN JF, HOFFMANN L, GUIGNARD C 2009 Simultaneous measurement of proline and related compounds in oak leaves by high-performance ligandexchange chromatography and electrospray ionization mass spectrometry for environmental stress studies. J Chromatogr A 1216 (7): 1094-1099. DOI: http://dx.doi.org/10.1016/i. chroma.2008.12.030

42. TOPIĆ M 2015 Fiziološki aspekti otpornosti hrasta lužnjaka (Quercus robur L.), cera (Quercus cerris L.) i crne topole (Populus nigra L.) u uslovima vodnog deficita -doktorska disertacija. PhD thesis, University of Novi Sad, Faculty of Sciences, Novi Sad, Serbia, 186 p 
43. LEI Y, YIN C, LI C 2006 Differences in some morphological, physiological, and biochemical responses to drought stress in two contrasting populations of Populus przewalskii. Physiol Plant 127 (2): 182-191. DOI: http://dx.doi.org/10.1111/ j.1399-3054.2006.00638.x

44. SZABADOS L, SAVOURE A 2010 Proline: a multifunctional amino acid. Trends Plant Sci 15 (2): 89-97. DOI: http://dx.doi. org/10.1016/i.tplants.2009.11.009
45. SCHWANZ P, POLLE A 2001 Differential stress responses of antioxidative systems to drought in pendunculate oak (Quercus robur) and maritime pine (Pinus pinaster) grown under high $\mathrm{CO}_{2}$ concentrations. J Exp Bot 52 (354): 133-143. DOI: http://dx.doi.org/10.1093/jexbot/52.354.133 
